\title{
MARRIAGE AND FAMILY IN SERBIAN LAW: A CONTEMPORARY PERSPECTIVE
}

\section{GORDANA KOVAČEK STANIĆ}

\section{Introduction}

"The family is the natural and fundamental group unit of society and is entitled to protection by society and the State." This definition was formulated more than 70 years ago in the Universal Declaration of Human Rights, but still applies today. Marriage and family are social and legal institutions that retain their importance in contemporary society while constantly changing in their appearance and content as they adapt to shifting norms. As a result, new family forms develop, including family in non-marital cohabitation, the binuclear family (as a consequence of joint exercise of parental rights after divorce or separation), and family formed as a consequence of using artificial reproduction technologies. ${ }^{1}$

\section{Marriage and family as universal human rights}

In Serbia, marriage and family are universal human rights and fundamental values. The Constitution of the Republic of Serbia" in Section 2 "Human and

1 Kovaček Stanić, Samardžić, 2020, pp. 557-558.

2 Constitution of the Republic of Serbia, Official Gazette of Serbia no. 98/06.

Gordana Kovaček Stanić (2021) Marriage and Family in Serbian Law: A Contemporary Perspective. In: Tímea Barzó, Barnabás Lenkovics (eds.) Family Protection From a Legal Perspective, pp. 191-220. Budapest-Miskolc, Ferenc Mádl Institute of Comparative Law-Central European Academic Publishing. 
minorities' rights" stipulates the following: "Everyone shall have the right to decide freely on entering or dissolving a marriage. Marriage shall be entered into based on the free consent of man and woman before the state body" (Art. 62/1, 2). "Families, mothers, single parents and any child in the Republic of Serbia shall enjoy special protection in the Republic of Serbia in accordance with the law" (Art. 66/1). "Everyone shall have the freedom to decide whether they shall procreate or not. The Republic of Serbia shall encourage the parents to decide to have children and assist them in this matter" (Art. 63).

These provisions are in accordance with 1948 UN Universal Declaration of Human Rights 1948 Article 16 (1): "Men and women ... have the right to marry and to found a family" and with Article 16 (3): "The family is the natural and fundamental group unit of society and is entitled to protection by society and the State."

\subsection{Social characteristics of marriage and family}

Statistical data show that marriage and family in contemporary societies become less stable. Today in Serbia marriage rate is about five in 1000 population. It decreased from 7, 5 thirty years ago. Approximately every fourth marriage ends in a divorce in 2011 and every third in 2018. However, there is a difference comparing divorce rate in the Republic of Serbia and the Province of Vojvodina thirty years ago. In Serbia app. every seventh marriage ended in a divorce at that time, thus in Vojvodina, every fifth marriage ended in a divorce. It could be noticed that the in Serbia during the period of thirty years divorce rate increased much faster than in Vojvodina. $^{3}$

Table 1

\begin{tabular}{|c|c|c|c|c|c|c|c|c|c|c|c|c|c|c|c|c|c|c|}
\hline \multirow[b]{2}{*}{ Year } & \multicolumn{9}{|c|}{ Marriage rate (1.000 population) } & \multicolumn{9}{|c|}{ Divorce rate (1.000 population) } \\
\hline & 1981 & 1990 & 2000 & 2006 & 2011 & 2017 & 2018 & 2019 & 2020 & 1981 & 1990 & 2000 & 2006 & 2011 & 2017 & 2018 & 2019 & 2020 \\
\hline Serbia & 7,5 & 6,2 & 5,5 & 5,4 & 5,0 & 5,1 & 5,2 & 5,1 & 3,4 & 1,0 & 1,1 & 0,8 & 1,2 & 1,3 & 1,3 & 1,4 & 1,7 & 1,2 \\
\hline Vojvodina & 7,6 & 6,0 & 5,9 & 5,2 & 4,9 & 5,4 & 5,5 & & & 1,6 & 1,3 & 1,1 & 1,1 & 1,1 & 1,7 & 1,8 & & \\
\hline
\end{tabular}

Table 2

\begin{tabular}{|l|c|c|c|c|c|c|c|c|}
\hline & & \multicolumn{7}{|c|}{ Divorces (number on 1.000 marriages) } \\
\hline $\mathbf{1}$ & Year & 1981 & 1991 & 2002 & 2006 & 2011 & 2017 & 2018 \\
\hline $\mathbf{2}$ & Serbia & 141 & 145 & 238 & 206 & 230 & 257 & 275 \\
\hline $\mathbf{3}$ & Vojvodina & 213 & 223 & 227 & 232 & 252 & 320 & 319 \\
\hline
\end{tabular}

3 Kovaček Stanić, Samardžić, 2019, pp. 235-244. 
The marital structures of urban and other rural settlements differ. The biggest difference is the percentage of divorces, which is almost double that of urban settlements. The urban population is an approximately $6 \%$ of the population over 15 years of age is divorced, but in rural areas it is almost 4\%. This might be associated with the fact that the rural population has maintained a more patriarchal model of family relations compared to the younger age structure and less traditional marital behavior seen in in urban areas. In urban areas, there is a higher percentage of unmarried and divorced persons and a smaller proportion of married persons and widowers.

Table 3

\begin{tabular}{|c|c|c|c|c|}
\hline \multirow{2}{*}{$\begin{array}{l}\text { Marriage status of } \\
\text { population" }\end{array}$} & \multicolumn{2}{|c|}{ Republic of Serbia } & \multicolumn{2}{|c|}{ Province of Vojvodina } \\
\hline & 2002 & 2011 & 2002 & 2011 \\
\hline \multicolumn{5}{|l|}{ Urban settlements } \\
\hline Single & 26.7 & 29.6 & 28.6 & 31.8 \\
\hline Married & 58.6 & 53.8 & 55.5 & 51.1 \\
\hline Widows/widowers & 9.6 & 10.5 & 9.8 & 10.4 \\
\hline Divorced & 5.1 & 6.0 & 6.1 & 6.6 \\
\hline \multicolumn{5}{|l|}{ Rural settlements } \\
\hline Single & 21.6 & 25.7 & 24.2 & 28.7 \\
\hline Married & 63.3 & 57.5 & 60.2 & 54.2 \\
\hline Widows/widowers & 12.5 & 13.4 & 12.4 & 13.0 \\
\hline Divorced & 2.6 & 3.4 & 3.2 & 4.1 \\
\hline
\end{tabular}

In Serbia it is common for women to be employed, but the employment rate is still higher for men. The employed population consists of $44 \%$ women and $54.3 \%$ men. However, there are differences in wages: men's wages are $16 \%$ higher than women's. The overall unemployment rate is $15.7 \%$ for the female population, and $11.1 \%$ for the male population.

Recently, there have been indications that more women than men lose their jobs. Women do a greater proportion of the housework than men, regardless of their employment status. There is a difference in the contribution of money/housework in urban vs. rural populations. Men in urban areas are more likely to engage in household work compared to men in rural areas. This is a consequence of the fact that a greater percentage of women are employed in urban areas as well as social differences, such as the patriarchal (traditional) family model, which regards men as the primary breadwinners. This model is accepted more in rural areas than in urban 
areas. Notably, the proportion of women as owners of immovable property in the public record of rights on immovable property is $29.7 \%$.

One of the causes of the crisis symptoms of marriage and family in Serbia is the negative population growth rate. According to vital statistics in 2011, the population growth rate was $-5.2 \%$. The birth rate was $9.0 \%$, while mortality rate was $14.2 \%$. The population growth rate for 2019 was $-5,5 \%$, and for $2020-7,7 \%$. The birth rate was $9,2 \%$ in 2019 , and $8,9 \%$ in 2020 ; and mortality rate was $14,6 \%$ in 2019 , and $16,6 \% 0$ in $2020 .{ }^{4}$

In the period from 2002 to 2011, the population decreased by approximately 241,000 , and the average annual growth rate was -3.3 per 1,000 inhabitants. In the same period, the share of the population younger than 15 years and older than 65 years in the total population changed: the percentage of young people (0-14) fell from $16.1 \%$ in 2002 to $15 \%$ in 2011 , while the proportion of those aged 65 and older increased from $16.6 \%$ (2002) to $16.8 \%$ (2011).

The other cause of crisis symptoms of marriage and family in Serbia is the emigration of young people from Serbia. In 2018, according to Eurostat information, over 50,000 people left Serbia. According to data provided by the Organization for Cooperation and Economic Development (OECD) and the International Monetary Fund (IMF) information, more than 400,000 people emigrated from Serbia to OECD countries during the period 2008-2016. A survey conducted by the Fridrih Ebert organization on more than 1,100 young people aged 14 to 29 years shows that three quarters of young people wish to emigrate. ${ }^{5}$

\subsection{Social and state protection of marriage and family}

Different laws in Serbia stipulate measures to protect the family. The first of these is the Family Act, which regulates marriage law, child (parental) law, and guardianship law. ${ }^{6}$

The Family Act stipulates value priorities for upbringing children: "Parents have the right and duty to develop a relation based on love, trust, and mutual respect with the child, and to direct the child towards adopting and respecting values of emotional, ethical, and national identity of his/her family and the society" (Art. 70).

The Serbian Constitution stipulates: "The Republic of Serbia shall promote understanding, recognition, and respect of diversity arising from specific ethnic, cultural, linguistic, or religious identity of its citizens through measures applied in education, culture, and public information" (Art. 48).

It could be said that this provision also prioritizes certain aspects that could (should) be applicable to children's upbringing.

\footnotetext{
4 Statistical Office of the Republic of Serbia, Monthly Statistical Bulletin 12/2020. Available at: https://bit.ly/2XmCh4Q, p. 36. I-XII 20198511 Æ I-XII 20209580.

5 See: https://bit.ly/3AbfqaE.

6 Family Act, Official Gazette of Serbia 18/05 with amendments, hereafter FA.
} 
The Constitution stipulates special protection of the family, mother, single parent, and child (Art. 66), while the Family Act regulates special protection of the family, mother, and child (Art. 2/1, Art. 5/2). The wording of the Constitution takes into consideration the situation of the single parent, regardless of whether it is the mother of the father, and seems to be more appropriate for the contemporary situation in practice. The Constitution provides special support and protection for the mother before and after childbirth. Special protection is provided for children without parental care and for children with impediments that affect their mental or physical development. The Serbian Constitution states everyone shall have the right to decide freely on entering or dissolving a marriage, i.e., marriage shall be entered into based on the free consent of men and women before the state body. Moreover, contracting, duration, or dissolution of marriage should be based on the equality of men and women.

The Serbian Constitution states that provisions on human rights shall be interpreted as the benefit of promoting values of a democratic society, pursuant to valid international standards in human rights, as well as the practice of international institutions that supervise their implementation. The Constitution shall guarantee, and as such, directly implement human rights guaranteed by the generally accepted rules of international law and ratified international treaties and other agreements. The law may prescribe a manner of exercising these rights only if explicitly stipulated in the Constitution or necessary to exercise a specific right owing to its nature, whereby the law may not under any circumstances influence the substance of the relevant guaranteed right (Art. 18). In addition, the Serbian Constitution states that all are equal before the Constitution and the law. Everyone shall have the right to equal legal protection, without discrimination. All direct or indirect discrimination based on any grounds, particularly on race, sex, national origin, social origin, birth, religion, political or other opinion, property status, culture, language, age, mental or physical disability shall be prohibited.

Special measures (affirmative action - positive discrimination) that the Republic of Serbia may introduce to achieve full equality of individuals or groups of individuals in a substantially unequal position compared to other citizens shall not be deemed discrimination (Art. 21).

The principle of equality between mother and father as parents and the equality of male and female children represents a more concrete version of the gender equality principle, which is stipulated in the Serbian Constitution signed in 2006. This principle was introduced into the domestic legal system through the Constitution of the Federal People's Republic of Yugoslavia in 1946. As a consequence, the mother and father have the same rights and obligations with respect to their children. Male and female children have the same rights in family and all other relations. Historically, in domestic law prior to World War II, the mother had an inferior status with respect to the father (pursuant to the institute of paternal authority), while female children had a considerably narrower set of rights than male children (pursuant to the Civil Code of the Kingdom of Serbia, 1844 female children possessed no inheritance rights).

The Serbian Constitution states that non-marital cohabitation shall be equal to marriage, in accordance with the law (Art. 62/5). Non-marital cohabitation is 
defined as the sustained cohabitation of a man and a woman between whom there are no marriage impediments (Art. 4 Family Act).

Regarding the legal nature of family norms, it could be stressed that some family law norms are imperative norms, thus parties are not able to change them by their will (e.g., norms on concluding marriage and divorce). Some family law norms are recommending and incentive norms (e.g., norms on the personal rights and duties of parents). Enforcement and imposition of sanctions in family law are specific, as in most cases, the sanction is quitting the existing relationship, while civil law sanctions are a coercive realization of obligations and damage compensation. In family law, there are methods to prevent and improve family relations; for example, the Center for Social Services (as a guardianship authority) can warn parents of deficiencies in the exercise of parental rights and refer parents for consultation with a family counseling service or an institution specialized in mediating family relations. Mediation, which has recently increased in importance, is a process that aims to help spouses and parents reach an agreement on important matters.

The self-determination principle is a tenet of contemporary family law. Self-determination gives spouses and parents several options for arranging their mutual relationships and relationships with minor children after divorce or separation. Divorce by mutual agreement is a form of divorce that is largely accepted in family law and family practice. The joint exercise of the parental right (joint custody) is possible even after divorce or separation of parents. Self-determination is possible in property relations in contemporary family law via the signing of a (pre)nuptial agreement between spouses. The other manifestation of the self-determination principle concerns the legal position of the child. In contemporary family law, the legal position of the child has been strengthened and children are acquiring rights earlier than before, along with the opportunity to exercise them independently.

As far as legislation is concerned, the Family Act contains most of the principles adopted in the UN Convention on the Rights of a Child 1989. Family law protection from domestic violence was introduced in Serbia in the Family Act, and the Law on Preventing Domestic Violence was enacted in 2016. ${ }^{7}$

Some acts that regulate other fields of law have provisions in order to protect the family. For example, the Law on Labor, enacted in 2005, stipulates the right to maternity leave and childcare leave. Maternity leave lasts for a period of three months after the child is born and childcare leave lasts for an additional nine months. Maternity leave is mostly provided for mothers; the father can only take it if the mother is unable to care for the child. On the contrary, leave for childcare is available for both mothers and fathers, depending on the parents' agreement. It is possible to share childcare leave between parents. The Law on Labor further encourages the birth of a third and fourth child as the maternity and childcare leave last for two years instead of the one year of leave provided for the first and second child. The Law on Biomedical-assisted Fertilization stipulates different procedures (technologies) available to men and women to 
help them become parents (not including surrogate motherhood). From 2020, procedures for the stimulating fertility are free of charge, limitless, ${ }^{8}$ as well as three embryo transfers are also free of charge for women up to the age of 43 . For the second child, two procedures for fertility stimulation are free of charge and one embryo transfer.

The Law on Financial Support for Families with Children ${ }^{9}$ stipulates different allowances, such as the parental allowance and child allowance. The parental allowance is the sum that parents receive as financial assistance when the child is born. This allowance is progressive and depends on the number of children. Parents' social status is not a factor in the receipt of this allowance. For the first child, the parental allowance is a lump sum of 100,000 din; for the second child, 240,000 din is paid in 24 monthly installments; for the third child is 1,440,000 din paid in 120 monthly installments; and for the fourth child 2,160,000 din is paid in 120 monthly installments. Given the obvious increase in payments for subsequent children, this is a birth-rate stimulative measure. The child allowance is a payment for the parents of the low social status. This law stipulates payments for maternity and childcare leave and the leave for the child care in accordance with Law on Labor.

The Law on Retirement and Disability Insurance ${ }^{10}$ favors the birth of a third child, stipulating that an insured's seniority - here, the seniority of a woman who gave birth to a third child - accrues during the two-year maternal leave as a special type of seniority (Art. 60). Changes and amendments to this Law in 2005 extended the rights of the children without both parents to receive not just one parent's pension but two separate family pensions (Art. 73/1). While this measure does not directly affect family planning, it is certainly significant as a measure that protects a child.

In Vojvodina, in 2004, the Assembly of the Autonomous Province of Vojvodina adopted "The Programme for Demographic Development of the AP Vojvodina with the Measures for its Implementation." One of the most important measures of this bill is the financial compensation offered for the third child, which would be paid to the mother in the amount of the average monthly wage in the province until the child has reached the age of 19 , regardless of whether the mother received an income. Unfortunately, this measure has not been applied due to a lack of funds. ${ }^{11}$

8 State Instructions for conducting biomedical assisted fertilization no. 06/2020.

9 Official Gazette of Serbia no. 113/17 i 50/18.

10 Official Gazette of of Serbia no. 34/03, 84/04, 85/05.

11 The condition for granting this compensation is proof that in the year when a third child was born the family has obtained an income per family member higher than the average salary in Vojvodina. Therefore, this measure is not social in its nature (it is restricted to well-off families), but is solely demographic in its character and stimulates the procreation of a third child. The measure is considerably expensive; it is estimated that in 2005 it would be necessary to provide $369600,000,00$ dinars for these purposes. Other measures include the following: for a third and a fourth child - financial help and provincial child benefit, full child's attendance at pre-school, maternity allowance, child benefit paid for the first child; two free procedures of artificial insemination, The Program for Demographic Development of AP Vojvodina with the Measures for its Implementation, The Assembly of the Autonomous Province of Vojvodina, Executive Council of AP Vojvodina, Provincial Secretariat for Demography, Family and Social Child Care, 2005. 


\subsection{International legal background and constitutional considerations}

According to the Serbian Constitution, ratified international documents are a direct source of law in Serbia.

"Generally accepted rules of international law and ratified international treaties shall be an integral part of the legal system in the Republic of Serbia and applied directly. Ratified international treaties must be in accordance with the Constitution" (Art. 16/2).

For family law, the most important conventions are as follows: the Convention on the Elimination of All Forms of Discrimination against Women ${ }^{12}$; the Convention on Consent to Marriage, Minimum Age for Marriage and Registration of Marriages ${ }^{13}$; the Convention on the Rights of a Child ${ }^{14}$; the Convention on the Civil Aspects of International Child Abduction ${ }^{15}$; the European Convention on Recognition and Enforcement of Decisions concerning Custody of Children and on Restoration of Custody of Children ${ }^{16}$; the Convention for the Protection of Human Rights and Fundamental Freedoms ${ }^{17}$; the Council of Europe Convention on Preventing and Combatting Violence against Women and Domestic Violence ${ }^{18}$; the Council of Europe Convention on the Protection of Children against Sexual Exploitation and Sexual Abuse ${ }^{19}$; and the Convention on the Protection of Children and Co-operation in Respect of Intercountry Adoption ${ }^{20}$. In 2009, Serbia signed, but has not yet ratified, the European Convention on the Adoption of 1967, which was revised in 2008.

One of the most important principles of European family law is the principle of respecting family life. This is stated in the European Convention on Human Rights, Art. 8:

"1. Everyone has the right to respect for his private and family life, his home, and his correspondence.

2. There shall be no interference by a public authority with the exercise of this right except such as is in accordance with the law and is necessary in a democratic society in the interests of national security, public safety or the economic well-being of the country, for the prevention of disorder or crime, for the protection of health or morals, or for the protection of the rights and freedoms of others." ${ }^{21}$

12 Ratified: Official Journal of Yugoslavia no. 11/81.

13 Ratified: Official Journal of Yugoslavia no. 13/64.

14 Ratified: Official Journal of Yugoslavia no. 15/90.

15 Ratified: Official Journal of Yugoslavia no. 7/91.

16 Ratified: Official Journal of Yugoslavia no. 1/01.

17 Ratified: Official Journal of Serbia and Montenegro no. 9/03.

18 Ratified: Official Gazette of Serbia no. 12/13.

19 Ratified: Official Gazette of Serbia no. 1/10.

20 Ratified: Official Gazette of Serbia no. 12/13.

21 Kovaček Stanić, 2002, p. 1. 
Authors Janis, Kay, and Bradley have commented on this provision:

"The phrasing in which this protection was stated, however, is unique in the Convention...Rather it speaks of a right to `respect for... private and family life`. Respect, as J.E.S. Fawcett pungently observed, 'belongs to the word of manners rather than the law." 22

The Serbian Family Act has a provision on respect for one's family life:

"Everyone has a right to have his/her family life respected" (Art. 2/2).

In contrast, the Serbian Constitution does not contain a similar provision. Historically, during the period where the state of Serbia and Montenegro existed, a constitutional document entitled "The Constitution Charter on State Union of Serbia and Montenegro" had a Charter on Human and Minority Rights and Civil Freedoms that contained a provision on respect for private and family life (Art. 24). ${ }^{23}$ It is not clear why similar provision was not stipulated in the subsequent 2006 Constitution of Serbia.

The most important decisions of the European Court of Human Rights involving Serbia, in connection with the violation of Article 8 (violation of family life) include the following: V.A.M. v. Serbia no. 39177/05; 13.3.2007; Tomić v. Serbia no. 25959/06 26.6.2007; Jevremović v. Serbia no. 3150/05. 17.7.2007; Damnjanović v. Serbia no. 5222/07. 18.11.2008; Felbab v. Serbia no. 14011/07. 14.4. 2009; Krivošej v. Serbia no. 42559/08. 13.10. 2010; and Jovanović v. Serbia no. 21794/08 26.3.2013.

In most cases, the issue before the court is the parent-child relationship. In two cases it concerns right to visitation (V.A.M. v. Serbia, Felbab v. Serbia and Krivošej v. Serbia), two cases concern entrusting the child to parental care (Tomić v. Serbia and Damnjanović v. Serbia), one establishes paternity of the father of a child born out-ofwedlock, (Jevremović v. Serbia), and one case concerns "missing" babies (Jovanović v. Serbia).

In Serbia, the issue of "missing" babies is a present problem. The specific act on this issue was adopted in March 2020: the Law on Establishing Facts on the Status of Newborn Children Suspiciously Missing from Maternity Hospitals in the Republic of Serbia. ${ }^{24}$ The aim of this Act is to establish facts for finding the truth on the status of newborn children suspiciously missing from maternity hospitals in the Republic of Serbia and to exercise the obligation of the Republic of Serbia arising from the judgment of the European Court for Human Rights in the case of Jovanović v. Serbia. 
The Constitutional Court of Serbia was called to assess the constitutionality of the provisions of the Family Act in the 9-year period (2007-2016) and found that no case determined their unconstitutionality. First, the Constitutional Court rejected the proposal to establish the unconstitutionality of the Family Act provisions that defines non-marital cohabitation as a lasting community of life for both men and women. Bearing in mind that by the constitutional provision itself, non-marital cohabitation shall be equal to marriage - which the Constitution has just defined as a community of life of a man and a woman - the Constitutional Court assessed that the disputed provisions of the Family Act were in accord with the aforementioned provision of the Serbian Constitution.

Subsequently, the Constitutional Court confirmed the constitutionality of the provisions of the Family Act on the obligation of parents to maintain their adult children who are incapable of working and lack sufficient means of subsistence.

The next crucial decision made by the Constitutional Court related to the Family Act, seeking to determine if the measure for temporary eviction of the perpetrator from a family apartment should have been dismissed. The Constitutional Court confirmed that in this case, "it was not a restriction of property rights but a temporary restriction of the manner of using the property that is permitted by the Constitution in order to protect the psychological integrity of the victim of domestic violence, and thus also for the public interest protection..." 25

Of great importance was the 2010 decision of the Constitutional Court of Serbia on a matter involving an individual's sex change. This decision ordered the municipal authorities to decide on the application for registering the individual's sex change. In this case, the applicant of the constitutional complaint was a person who had had sex reassignment surgery but was not able to change the sex recorded in the administrative register, as the municipal authority declared itself incompetent, citing the Serbian Law on Registration of Births, which does not provide such a possibility. In this case, the Constitutional Court assessed that the principles of protection of human dignity and free development of personality should prevail.

Therefore, the Court ordered the competent municipal authority to decide on this request for registration of the individual's sex change. ${ }^{26}$

The possibility of changing one's sex was introduced into the Law on Registrations of Births in 2018 when this Act was amended. ${ }^{27}$ Specifically, Article 45b was added, which stated that sex is changed could be registered in the register of births on the basis of health institution certificate. This certificate might be issued on the ground of at least one year of hormone therapy for a person whose sex is in the process of transition or on the grounds of surgical intervention resulting in his/her sex change. 


\subsection{Separation and cooperation of church and state in marriage law}

In Serbian Family law, civil marriage is obligatory; thus, marriage concluded in a religious form does not have any legal consequences. Solemnization of religious marriage before the civil marriage was considered a crime until 1994, when this criminal offense was eliminated from the Serbian Criminal Act. In Serbia, civil marriage has been obligatory since the adoption of new rules after the Second World War — the 1946 Yugoslav Principle Law on Marriage. In the province of Vojvodina, civil marriage was obligatory much earlier because Hungarian law was in force before the Second World War (Law on Marriage 1894, para. 29/1, which required civil marriage). Nowadays, there is a widely accepted custom in Serbia to conclude marriage in a religious form apart from the civil. There is no precise provision in the effective law in which religious forms of marriage may be solemnized. Taking into account constitutional provisions related to the prohibition of discrimination, which includes a ban of discrimination based on religion (Art. 21/3), one may conclude that marriage may be solemnized based on the rules of all the recognized religious groups to which the future spouses belong.

In the Serbian orthodoxy, religious marriage is regulated by the Marriage Rules of the Serbian Orthodox Church. ${ }^{28}$ Specifically, marriage is defined as "a holy sacrament in which two persons of the opposite sex attach themselves to one another, in the way prescribed by the Church through a spiritual and physical relationship, for the purpose of complete cohabitation and upbringing of children." Some minorities in Vojvodina, (e.g., the Hungarian minority, which is the largest minority group) accept the Catholic religion. The Catholic Church regulates marriage according to the Code of the Canon Law, wherein marriage is defined as an "alliance (matrimonial foedus) in which the husband and wife are establishing cohabitation, which is in its nature aimed at spouses' welfare and birth and upbringing of children" (Canon 1055, para. 1). The Code also uses the term "marriage contract" (matrimonialis contractus), but it gives priority to the alliance rather than the contract. ${ }^{29}$

The principal distinction between the civil contemporary definition of marriage and definitions of marriage according to religious law is the permanence or impermanence of the marriage. The Family Act has excluded the element of duration of marriage, although this does not imply, neither from the theoretical nor from a practical point of view, its brevity. Spouses today still get married with the desire for a long and harmonious marriage, but if this cannot be achieved for some reason, they have an option to get a divorce. In contrast, religious law views marriage as a lifetime union dissolved only by the death of one spouse. The other significant difference is that religious definitions view marriage as a sacrament (holy mystery). The principle of monogamy as a basic rule in marriage relations is prescribed in

28 Marriage Rules of the Serbian Orthodox Church, $2^{\text {nd }}$ supplemented and corrected issue of the Holy Bishops Synod, paragraph 1-2, Belgrade, 1994.

29 Nuić, 1985, p. 337. 
both civil and religious law. The significant distinction between Christian Orthodox rules and Catholic rules concerns divorce. As opposed to the Catholic Church, the Orthodox Church allows divorce. ${ }^{30}$

\section{Marriage and family in Serbian family law}

The Serbian Family Act does not contain a definition of what constitutes a family. There are several reasons for this approach. One is that family law regulates family relations and relations among family members, so, while it enjoys civil and social protection under the Constitution the family itself is generally not the holder of the rights and duties. Another reason is that a precise definition of the family will lead to restrictions on the term "family." Family relations, however, tend to develop quickly - there are new forms of family unknown in earlier historical periods that would otherwise remain outside the concept of a family if the definition of family determined exactly who can be considered a family member. ${ }^{31}$

In modern times, the most common family type is the nuclear family, consisting of parents and their immediate children. Some authors take a narrower definition to include only parents and children residing together. In contrast to this modern form of family, in Serbia's past, the extended family, as a broader definition of family, was of great importance. The extended family consisted of all relatives who lived and worked together. The Serbian Civil Code (1844) regulated the legal status of the extended family, providing that the extended family is a legal entity (Para. 57). Today, Serbian family law attaches importance to extended families, regulating property relations among members of family who live and work together through a special form of property that results from this situation: community property (Art. 195 FA). However, in modern times, the extended family as a form of family in Serbian society is the exception, as nuclear families prevail.

Cohabiting couple families, family based on adoption, and family created through medically assisted reproduction have gained greater legal significance in modern times. Additionally, an entirely new form of family, the so-called binuclear family, has arisen as the result of joint parental custody in a situation where the parents do not live together.

Societies have an interest in protecting the family, primarily because of their reproductive function and the role in renewing the population. Upbringing, education, and psychological support for children are primarily achieved within the family

30 Kovaček Stanić, 2011, pp. 811-813.

31 Kovaček Stanić, Samardžić, 2019, pp. 235-244. 
sphere. These functions of the family affect the development of a child's personality and his/her upbringing to be responsible members of society upon reaching adulthood. However, questions remain over whether the principle of special protection of the family is implemented sufficiently in practice or whether such protection is provided to families who are unable to perform their functions according to modern standards.

The Serbian Family Act defines marriage as cohabitation between a man and woman governed by the law (Art. 3/1). According to this definition, the basic elements of marriage are cohabitation between two persons of the opposite sex and monogamous cohabitation (cohabitation of one woman and one man), which is governed by the law. Cohabitation is a complex relationship, which implies different relationships between spouses, based on love, including intimate relationships, respect, support, and economic relationships. If marriage is entered into in order to achieve a goal other than the intent to cohabitate (e.g., acquisition of citizenship, work permit, domicile, habitual residence, inheritance, housing rights, or other property rights), it is considered fictitious and invalid (Art. 16).

There is a tendency in contemporary family law to reduce marriage impediments, which in turn leads to the liberalization and facilitation of marriage formation. According to the Serbian Family Act, the substantial requirements are the following: opposite sex, expression of will to marry, cohabitation, and lack of marriage impediments (existing marriage, mental incapacity, minority, lack of free will, kinship by blood or adoption, affinity, and guardianship) (Arts. 15-24).

Marriage may only be solemnized between two persons of the opposite sex, i.e., a woman and a man. In Serbia, there is no act that governs the same-sex union (registered partnership or marriage), nor does any statute govern the legal status of persons who changed their sex (transsexuals). At present, a law to govern same-sex unions is in the process of being drafted.

Non-marital cohabitation between men and women in Serbian law constitutes a de facto relationship, so it is not possible to register it. Consequently, there can be difficulties in proving the existence of non-marital cohabitation in legal proceedings. Under Serbian family law, heterosexual non-marital cohabitation is regulated by the Article 4 of the Family Act. At the outset, it is important to emphasize that heterosexual non-marital cohabitation only has legal consequences if the legal requirements for the establishment of non-marital cohabitation are first met. These requirements are as follows: absence of marriage impediments (existing marriage, underage, kinship relation, adoption relationship, affinity relationship, mental incapacity, lack of free will to consent to marriage and guardianship). In addition, the non-marital cohabitation must be a sustained relationship. If non-marital cohabitation does not meet these requirements at the moment of its establishment, the court should apply civil law norms to the acquisition of property. However, if impediments cease to exist, non-marital cohabitation becomes lawful.

In Serbia, the statutory property regime in marriage and non-marital cohabitation is the community property regime. Community property is the property that 
spouses/partners acquire through work while living together (Art. 171). The property that a spouse/partner acquires before marriage remains separate property; thus, assets acquired pre-marriage will remain individual property. Likewise, property that a spouse/partner acquires during marriage by inheritance, gift, other legal acts whereby rights are acquired exclusively, or by the division of community property is treated as his/her separate and individual property (Art. 168).

The (pre)nuptial contract was introduced in Serbian law by the 2005 Family Act. The authority for issuing the (pre) nuptial contract now belongs to the notary public (Law on Notary Public 2011 Art. 82/1/10, 11). ${ }^{32}$ According to the amendments to the 2015 Family Act, the form of (pre) nuptial contract is notarial solemnization of the legal document (Art. 188). According to Serbian law, waiving the right to maintenance has no legal bearing (Art. 8 of FA); consequently, this cannot be a content of a (pre)nuptial contract. The (pre)nuptial contract is also available to partners engaged in non-marital cohabitation.

The right of a child and a parent exercising parental rights to live in an apartment owned by the other parent (habitatio) represents existential protection, especially designed for children, but also for parents who exercise parental rights. Habitatio is also available to spouses and partners in the situation of non-marital cohabitation. The condition for acquiring habitatio is that the child and the parent exercising parental rights do not have property rights to an unoccupied apartment. The right to residence lasts until the child acquires maturity. However, the child and the parent do not have the right to residence if the acceptance of their request for the right to residence would present manifest injustice for the other parent (Art. 194 FA).

The right and obligation of maintenance is a dual consequence of the creation and termination marriage and non-marital cohabitation (Arts. 151, 152 FA). A spouse/ partner who lacks sufficient means of support and is unable to work or is unemployed (due to no fault of his/her own), has the right to maintenance from his/her spouse/partner in proportion to the spouse/partner's capacity. Thus, in order for the spouse/partner to have the right to maintenance, certain conditions must first be fulfilled and evidence provided indicating that the spouse/partner was unable to independently provide for his/her existence. There are two cumulative conditions, taking into account that the second condition consists of two alternative components. The first condition, - insufficient means of support - is considered to be fulfilled in a situation where the spouse/partner lacks the means to support him or herself or is in a situation where such means are insufficient for the fulfillment of basic needs. For example, a spouse/partner has an apartment or house, which is a place to live, but has no regular income that would satisfy other needs such as the need to maintain monthly rent or mortgage payments.) The second condition - the inability to work - can be permanent or temporary, complete or partial; for example, as a result of illness or old age. Unemployment, as an alternative component, should come about due to no fault of the spouse/partner. The condition on the side of the debtor (capable 
spouse) is his or her ability to provide maintenance. These conditions are objective in nature. Although the concept of fault as a category has been abandoned in family law, the right to maintenance is not quite objective. As aforementioned, the spouse/ partner can lose the right to maintenance if the acceptance of his/her request for maintenance would represent manifest injustice for the other spouse/partner (Art. 151/3 FA).

The amount of maintenance must be determined in accordance with the requirements of the maintenance creditor and the capacities of the maintenance debtor. The needs of the maintenance creditor depend on his/her age, health, education, property, income, and other circumstances that significantly contribute to the determination of the amount owed as maintenance (Arts.160-167 FA). The capacity of the maintenance debtor depends on his/her income, possibility to find employment and earn wages, his/her property, his/her personal needs, any obligations to maintenance other persons, and other circumstances that significantly contribute to the determination of maintenance. The standard of living during a relationship is not one of the statutory criteria. However, the contribution in practice would indirectly depend on the standard of living during the relationship, as the needs of the maintenance creditor would be different depending on the standard of living. Generally, the contribution is determined in terms of monetary support. However, it may also be determined in other terms in the case that both the maintenance creditor and debtor agree. The maintenance creditor may, at his/her own choice, request that the amount of maintenance be determined as a fixed monthly amount or as a percentage of the regular monthly pecuniary income of the benefactor. If the amount of maintenance is determined as a percentage of the regular monthly pecuniary income of the benefactor (salary, pension, royalties, and other compensation), the amount of maintenance, generally speaking, must be between $15 \%$ and $50 \%$ of the regular monthly pecuniary income of the maintenance debtor, minus the amount of taxes and contributions to compulsory social insurance. The possibility of calculating the amount of maintenance in percentage terms was introduced into Serbian law in 1993, at a time of hyperinflation, as a fixed sum was losing its value on a daily basis. ${ }^{33}$

According to FA, maintenance may last for a definite or an indefinite period of time, but is typically limited to a specific period. The maintenance of a partner after the termination of a marriage or non-marital cohabitation may last no longer than five years. However, there is a safeguard clause that provides that in exceptional situations the maintenance may be prolonged longer than five years, particularly if justifiable reasons prevent the spouse maintenance creditor from working (e.g., old age).

The main legal difference between marriage and non-marital cohabitation is that there are no hereditary rights between partners explicitly stated in or supported by the law (Law on Inheritance 1995). However, it is possible to make a testament and nominate a partner as an heir.

33 Law on Marriage and Family Relationships 1980 - amendments in Official Gazette of Serbia no. 22/93, 25/93, and 35/94. 
In social law, partners have equal rights as spouses (Law on Financial Support for Family with Children, Law on Retirement and Disability Insurance).

Other forms of unions, e.g., same-sex unions, are not regulated in Serbian law. However, a law concerning same-sex unions is in being drafted. The 2021 Draft Law on Same-Sex union regulates two types of same-sex unions: registered same-sex unions and de facto same-sex unions; thus, parallelism of concepts exists.

A registered same-sex union is defined as the union of the family life of two same-sex persons, which is concluded by a competent organ. An unregistered (de facto) same-sex union is defined as the union of family life of two same-sex persons that is not concluded by a competent organ. This union has legal effects only if there are no impediments for its conclusion and if it lasts for a period of three years (Art. 2, Art. 66).

A same-sex union is concluded by affirmative and uniform statements in order to realize the cohabitation given before the registrar (Art. 8). A same-sex union is to be concluded before the registrar in a solemn manner and in a room specially designated for this purpose. The registrar may, exceptionally, allow for a same-sex union to be concluded in another venue if there are justified reasons for doing so. The future partners, two witnesses, and the registrar are to be present at the conclusion of samesex union. Any person having legal capacity may be a witness to the conclusion of the same sex union (Art. 14). A same-sex union is terminated by the death of a partner, proclaiming missing person is dead, by annulment, or by cancellation (break) (Art. 18). A same-sex union can be cancelled in court proceedings, or exceptionally by registrar (break by agreement) (Art. 26). Each partner has the right to a court cancellation (break) of a same-sex union by action or agreement. If the relations are seriously and permanently disturbed or if the same-sex union cannot be realized, the termination is by an action. If both parties are in agreement, the partners must include a written agreement on the division of community property (Art. 27). It is stipulated in the Draft that, exceptionally, a same-sex union can be cancelled by providing consensual statements of will to withdraw the union to the registrar.

The legal effects of same-sex unions are similar to the legal effects of marriage. Regarding personal effects, same-sex partners consensually and jointly decide on all important matters for their life together, have the right to protect the privacy of their family life and right to mutual cooperation, and have a duty to help each other and to care and provide assistance in the case of illness (Art. 30). Finally, same-sex union partners may agree on any changes to their surnames.

Another family law effect concerns property rights. Partners might have separate and community properties, similar to spouses and heterosexual partners in nonmarital cohabitation (Art. 38). The contract on property is available to same-sex partners, during or before conclusion of a same-sex union (Art. 46). Another family law effect is maintenance; partners in same-sex unions have both the right and duty of maintenance (Art. 35).

The Draft Law stipulates rights and duties between same-sex partners and the child of the other partner. A partner in a same-sex union has a duty to maintain a 
child of the other parent if a child does not have relatives who have a duty of maintenance or if they lack sufficient means to do so. The duty to maintain a child of the other partner exists even if the union ceases to exist due to death of one partner if cohabitation continued until death. If a same-sex union ends by annulment or by cancellation, a partner's duty to maintain the child of the other partner also ends (Art. 36).

A partner in a same-sex union who is not a child's parent has the right to make decisions on necessary and urgent acts in the interest of the child when there is a danger to the health and/or life of a child. Another legal effect of same-sex unions is domestic violence.

Same-sex partners in registered unions have the inheritance rights as spouses (Art. 47). However, same-sex partners in de facto unions do not have inheritance rights that are similar to the position of heterosexual partners in non-marital cohabitation.

According to health law, a same-sex partner has the right to information about the illness and its treatment and to participate in decision-making on the medical treatment of the partner who is ill. If the partner is incapable of giving consent to medical treatment, the other partner has equal rights and duties as a spouse (Art. 32). If one of the partners is in the hospital, the other partner has the same visitation rights as spouses (Art. 33).

Partners in same-sex unions have the same rights as spouses in criminal proceedings. The partner who is in jail has the right to receive parcels from his/her partner and to visitation rights as a spouse (Art. 31).

Partners in same-sex unions have equal status as spouses under tax law, pension law, labor law, laws governing the acquisition of nationality, health insurance law, social protection law (including child protection law), tort law, etc. (Arts. 48-55).

A de facto same-sex union has the same effects on personal relations, children, property rights as registered same-sex unions (Art. 67). The effects on pension rights, social security, health insurance, and labor law are the same as the effects of nonmarital cohabitation of two persons of the opposite sex (Art. 68).

The 2017 Law on Biomedical Assisted Fertilization stipulates different procedures available to men and women to help them become parents. These procedures are available to heterosexual couples, spouses, and partners engaged in non-marital cohabitation. Exceptionally, woman living alone are entitled to the right to infertility treatment by biomedical-assisted fertilization (adult, legally capable woman) (Art. 25). In practice, it would also be possible for the woman in the same-sex union to use biomedical procedures if they claim that they live alone. This would be easy, especially if the union is a de facto one, as there is no registration thus and no evidence of existing union. Therefore, although the Draft Law on same-sex union does not include reproductive rights and the availability of biomedical technologies to samesex partners, in practice this could happen.

Serbian Draft Law could be classified as a group of laws that regulate registered same-sex unions with legal effects that are similar to the legal effects of marriage. 
The process for creating and dissolving same-sex unions is similar to that of marriage and divorce. That is, comparable conditions and procedures exist for the conclusion of a same-sex union and marriage and for establishing the grounds for divorce and dissolution of a same-sex union. It might be a better solution for the contemporary Serbian situation, keeping in mind social circumstances and the general views of the population, to start by regulating the same-sex union as a registered partnership, an institution that differs from marriage. For example, in some countries, jurisdiction for the registration of registered partnerships has a court (France: Du pacte civil de solidarité et du concubinage - PACS). On the contrary jurisdiction for concluding the marriage has administrative organ. ${ }^{34}$

\subsection{Legally recognized forms of family relationships}

According to the Constitution and Family Act, a child born out of wedlock has the same rights as a child born in wedlock (Art. 64 Constitution and Art. 6/4 FA). The status of a child born out of wedlock does not depend on whether the child is born in a situation of non-marital cohabitation or non-marital cohabitation never existed. This principle was introduced into the domestic legal system with the 1946 Yugoslav Constitution. However, the equal status of children born in and out of wedlock was incomplete at first. The illegitimate child had legal relations with his mother and her relatives, but the father had to acknowledge the child in order for him/her to obtain all the rights and obligations in relation to the father and the father's relatives. However, if paternity was established through court proceedings, the child entered into legal relations with his/her father only and not with his relatives. In the jurisprudence, there was a view that a child acquires the rights and obligations in relation to paternal relatives if the father accepts the child after the court's decision. The complete equalization of the status of the children born in and out of wedlock came into effect via the 1974 Constitution. Today, children have the same rights and obligations in respect to both parents and their relatives, regardless of the existence or non-existence of marriage at the time of their birth. In modern times, the number of children born out of wedlock has increased. In Serbia, 24\% of all children are born to unmarried parents, which is the reason for the change in the social attitude towards them. Children born out of wedlock should no longer be stigmatized. The only difference in the legal status of children born in and out of wedlock exists in the method of determining paternity.

The principle from ancient Roman law pater vero is est, quem nuptiae demonstrant accepted until now. Under Serbian law, the husband of the child's mother is to be considered the father if a child was born within 300 days after the termination of the marriage, but only if the marriage was terminated owing to the death of the

34 Rubellin-Devichi, 2000, pp. 158-164; Martin, Théry, 2001, p. 152. 
husband and if the mother does not enter into another marriage during this period. The husband from the new marriage of the child's mother is to be considered the father of a child born during that marriage, regardless of how short a time may have elapsed between the termination of one marriage and the commencement of the other (Art 45/1-3 FA).

If a child born out of wedlock, paternity has to be established by the father acknowledging the child as his own or by a court judgment (Art. 45/4 FA). A person who has reached 16 years of age may acknowledge paternity (Art. 46 FA). Paternity may be acknowledged only if the child is alive at the moment of acknowledgment. Acknowledgment of paternity before childbirth is accepted, but only if the child is born alive (Art. $47 \mathrm{FA}$ ). The acknowledgement takes effect only if the mother and, under certain circumstances, the child consent to the father's acknowledgment. The mother and child can consent if they are at least 16 years of age (Art. 48/1 and Art. 49/1 FA). If either the mother or the child cannot consent, the consent of one of them is sufficient (Art. 48/2 and Art. 49/2 FA). If neither the mother nor the child can consent, the ability to consent to the acknowledgment of paternity is conferred to the child's guardian with prior establishment of his/her guardianship authority (Art. $50 \mathrm{FA}$ ).

Thus, the acknowledgement is not a unilateral act. These provisions vividly illustrate the principles of family autonomy. The acknowledgment depends almost entirely on the will of the parties concerned. If the man acknowledges his paternity and the mother (or a child older than 16) consents to it, this man is considered the father. The biological truth is not examined.

In Serbian law, paternity can be contested. In the case of a child born in wedlock, the mother, the child, the husband, and another man (who claims to be the father) could initiate proceedings to contest paternity and rebut the presumption of the husband's paternity (Art. 56). When adopting the Family Act, the legislature decided to synchronize the deadlines in all the maternity and paternity disputes by providing all parties, except the child, with a subjective deadline of one year from learning the relevant facts and an objective deadline of ten years from the child's birth. The deadline for the child is unlimited, so if it is in the interest of the child to initiate the procedure before he or she reaches legal age, the procedure will be initiated by his or her legal representative and, after reaching the legal age, by the child him or herself. If the child's interests collide with the interests of his legal representative, the guardianship authority will appoint a so-called "collision guardian to the child" (Art. 132/2 item 3 and Art. 265 FA).

Challenges to paternity can also be brought regarding children born out of wedlock. However, only the man claiming to be a child's father may initiate an action to contest the paternity of the man considered to be the child's father on the grounds of the acknowledgment. The mother, the father, and the child cannot contest paternity based on acknowledgment, as they consented to acknowledgment. If the paternity of the child born out of wedlock is established by a court decision, it cannot be contested at all (Art. $56 \mathrm{FA}$ ). In the proceedings for contesting paternity, the court 
is obliged to determine the biological truth, which may be based on DNA and other biomedical evidence.

The mother's husband or partner is to be considered the father of a child conceived through biomedical assistance, provided he has granted written consent to the procedure of biomedical-assisted fertilization (Art. 58 FA).

The paternity of the man considered to be the child's father may not be selfcontested, but an exception is made if he suspects that the child was not conceived through the procedure of biomedical-assisted fertilization. In this situation, he can contest paternity within one year from the day of learning that the child was not conceived through a procedure of biomedical-assisted fertilization, but no later than ten years from the birth of the child. If a child is conceived through biomedical assistance by donated semen cells, the paternity of the man who donated the semen cells may not be established (Art. 58/5 FA).

For a long time in legal history the matter of child maternity was rarely an issue. The principle of ancient Roman law, mater semper certa est etiam si vulgo conceperit, was broadly accepted, i.e., mother was the woman who gave birth to the child. In contemporary family law, statutory provisions often establish or define motherhood. The same is true in Serbian family law. The Family Act contains a provision explicitly stating that a woman who gave birth to a child is to be considered the child's mother (Art. 42). In addition, maternity can be established by a court decision in the exceptional instance of a woman who gave birth to a child who was not entered into the register of births indicating the identity of the mother. The child and the woman claiming to be the child's mother both have the right to establish maternity. A child may initiate an action to establish maternity at any time, and a woman claiming to be a child's mother may initiate an action to establish her maternity within a year of learning that she gave birth to that child (but no later than ten years from the birth) (Art. 249). Maternity can also be contested. This procedure is necessary in cases where the wrong data of a child's mother have been entered into the register, in the case of default or substitution of children, or the use of someone else's health identification card in a delivery hospital. In a number of cases, false documents are used in the hospital because the mother does not have medical insurance and is unaware that medical services to assist in giving birth is free, regardless of insurance. Although in such cases there is no dispute as to maternity, court proceedings must be initiated so that maternity can be properly established.

A child may initiate an action to contest maternity, regardless of the time limit. A woman entered in the register of births as a child's mother may initiate an action to contest her maternity within one year from the day of learning that she did not give birth to that child, but no later than ten years from the birth of the child. A woman who claims to be a child's mother may initiate an action to contest the maternity of the woman entered in the register of births as the child's mother within one year from the day of learning that she gave birth to that child, and no later than ten years from the birth of the child. A man considered to be the child's father under this Act may initiate an action to contest maternity within one year from the day of 
learning that the women entered in the register of births as the child's mother did not give birth to the child, and no later than ten years from the birth of the child (Art. 250 FA). There are some restrictions to contesting maternity. Maternity may not be contested if established by a final court judgment, after the adoption of the child, and after the death of the child (Art. 44 FA).

If the child is conceived via biomedical assistance, the mother of the child is the woman who gave birth to the child. If a child is conceived through biomedical assistance by a donated ovum, the maternity of the woman who donated the ovum may not be established (Art. 58 FA). The Law on Biomedical Assisted Fertilization forbids surrogacy in such a way that it specifically prohibits the inclusion of a woman who intends to give the child to a third party with or without paying a fee or achieving any tangible or intangible benefits, as well as offering surrogate mother services by women or other individuals with or without charges or other tangible or intangible benefits (Art. 49/18).

According to the Law on biomedical assisted fertilization, the right to infertility treatment by biomedical-assisted fertilization procedures has adult and legally capable men and women, who are in need of help for biomedical assisted fertilization, who live together in accordance with the law governing family relationships - spouses or partners in non-marital cohabitation. They should be able to perform parental duties in the best interest of the child, considering their psychosocial conditions. Exceptionally, the right to infertility treatment by a biomedical-assisted fertilization procedure is entitled to an adult and legally capable woman living alone who is able to perform parental duties in the best interest of the child, Art 25. Thus, in the majority of cases, families formed with biomedical assistance will consist of both parents and a child, and only exceptionally will consist of the mother and child.

The Constitution of Serbia and the Family Act includes the principle of equalization of adoption with parenting, the Art. 6/5 Constitution, and Art. 7/4 FA. According to the Family Act, a child can be adopted if it is in their best interests, (Art. 89). Only a minor may be adopted, but not before reaching the third month of life (Art. 90). The family status of the adoptee has to be as follows: a child who has no living parents, a child whose parents are unknown, or their dwelling place is unknown; a child whose parents are fully deprived of parental rights; a child whose parents are fully deprived of legal capacity; a child whose parents gave their consent to adoption (Art. 91). A parent gives his/her consent to adoption with or without designating the adopters (Art. 95/1). A child who has reached ten years of age and who is capable of reasoning gives his/her consent to adoption, as well (Art. 98/1). The Family Act stipulates that spouses or cohabitees may adopt together. This ensures that the child grows up in complete families that have two parents, both mother and father. It is permitted for the person who is a spouse or a non-marital partner of the child's natural parent to adopt a child, in which case the child will have two parents, one natural and the other by adoption. Exceptionally, the minister responsible for family protection may grant adoption to a person who lives alone if there are justified reasons for doing so. The difference in age between the adopter 
and the adoptee must not be less than 18 years or more than forty-five years (Art. 99/1). Only a person for whom it has been established that he/she possesses personal characteristics upon which it may be concluded that he/she will exercise his/her parental rights in the best interest of the child may adopt. The following persons may not adopt: a person fully or partially deprived of parental rights or of legal capacity, a person suffering from an illness that may have detrimental effects on the adoptee, a person convicted for a crime belonging to the group of crimes against marriage and family, against sexual freedom and against life and body (Art. 100). Adoption results in the establishment of the same rights and duties between the adoptee and his/her offspring and the adopters and their relatives, as between a child and his/her parents and other relatives (Art. 104). Adoption terminates the parental rights of parents and the rights and duties of the child toward his/her relatives and the rights and duties of the child's relatives (Art. 105). Adoption may not be rescinded, but may terminate by annulment, if it is null and void or voidable (Art. 106).

\subsection{Legal framework of parent-child relationship}

Parental rights are derived from the duties of the parents and exist only to the extent necessary for the protection of the personality, rights, and interests of the child (Art. 67). Parents have the right and duty to care for their children. Taking care of the child includes protection, raising, upbringing, education, representation, and maintenance ${ }^{35}$ of the child and management and disposal of the child's property (Art. 68). Parents have the right and duty to protect and raise the child by personally taking care of their lives and health. Parents may not subject the child to humiliating actions and punishments that insult the child's human dignity and have the duty to protect the child from such actions by other persons. Parents may not leave the child of pre-school age, unsupervised. Parents may temporarily entrust the child to another person only if that person meets the requirements for being a guardian (Art. 69). Parents have the right and duty to develop a relationship based on love, trust, and mutual respect with the child, and to direct the child towards adopting and respecting values of emotional ethical and national identity of his/her family and society (Art. 70). Parents are under the obligation to provide elementary education to children and have the duty to take care of the child's further education according to their possibilities. Parents have the right to provide the child with education that is in accordance with their religious and ethical beliefs (Art. 71). Parents have the right and duty to represent the child in all legal operations and in all proceedings exceeding the limits of the child's legal capacity and capacity to be a party in the proceedings (legal representation) (Art. 72).

In Serbian law, the stepparent (the blood parent's new spouse) has the obligation to maintain a minor stepchild, during the marriage and after termination of marriage by death of the biological parent (not if the marriage between his/her parent 
and stepmother or stepfather has ceased by annulment or divorce). A stepparent has the right to get maintenance from his/her mature stepchild if the stepparent is unable to work and lacks sufficient means of maintenance in proportion to stepchild capacities. A stepparent does not have the right to maintenance if the acceptance of his/her request for maintenance would present manifest injustice for the stepchild (Art. 159).

A child has the right to maintain personal relations with relatives and other persons he/she is particularly close to, if that right has not been limited by a court decision (Art. 61/5). The stepparent is included as an in-law relative (affinity).

In Serbian family law, parents exercise parental rights jointly and consensually when they cohabitate. Married parents automatically acquire parental rights at the moment of childbirth. If parents are not married, the mother automatically acquires parental rights at the moment of the birth of the child and father when paternity is established (by father's acknowledgment or by court judgment). Thus, if parents cohabitate and if paternity is established when parents are not married, parents exercise parental rights jointly and consensually. ${ }^{36}$

When parents do not live together, there are two forms of exercise of parental rights: joint and independent. In the Serbian legal system, joint exercise of parental rights in situations where parents do not cohabitate has been introduced in Serbian family law by the Family Act 2005. The parents might not cohabitate as a consequence of parental divorce, annulling their marriage, separation, terminating heterosexual non-marital cohabitation, or if parents never lived together.

A provision states that parents may continue to exercise parental rights jointly even after they do not lead a common life, provided that they make an agreement on joint exercise of the parental rights and provided that the court is satisfied that this agreement is in the best interests of the child (Arts. 75-76 FA). This kind of parental agreement enables parents to exercise all the rights and duties comprised within parental rights if they do not lead a common life. It is intended to avoid the hostility and antagonism caused by court decision granting the exercise of the parental rights to one of them. The wording of the provision on joint exercise of the parental rights confers great freedom upon the parents because it enables them to agree on matters related to their child in a manner that is most appropriate for their own particular situation. The only limitation is the parents duty to reach an agreement on the issue of the child's domicile (Art. 75/2 FA). The domicile, followed by the child's address, must be established for the sake of legal certainty, and especially for the sake of facilitating legal acts (communication of legal documents, notification, etc.). In the opinion of the Commission that produced the Draft, this limitation does not necessarily mean that the parents cannot agree on the alternating residence of the child (factual joint custody). 
The other form of exercise for parental rights is sole (independent) exercise. In Serbian family law, one parent exercises parental rights independently when the other parent is unknown, has died, or is fully deprived of parental rights or legal capacity, when the child lives with this parent only, and the court has not yet made a decision on the exercise of parental rights. One parent exercises parental rights alone on the basis of a court decision when the parents do not cohabitate: if they do not conclude an agreement on the exercise of parental rights; if they have concluded an agreement on joint or independent exercise of parental rights, but the court finds that this agreement is not in the best interest of the child; if they conclude an agreement on independent exercise of parental rights, and the court finds that this agreement is in the best interest of the child (Art.77 FA).

The other parent who does not exercise parental rights has the right and duty to maintain the child, to maintain personal relations with the child, and above all, she/ he has the right to decide, jointly and consensually with the parent exercising the parental rights, on issues that significantly influence the child's life (Art. 78/3 FA). The issues considered to have a significant influence on the child's life, in terms of the Serbian Family Act 2005, are specifically: the education of the child, significant medical interventions on the child, the change of the child's residence, and the disposal of the child's property of great value (Art. 78/4).

The right of the other parent to decide on issues that significantly influence the child's life, jointly and consensually with the parent exercising the parental rights, is a solution that existed in Serbian law before joint exercise as a form of exercise of the parental rights of parents who do not live together was formally introduced (Law on Marriage and Parental Relations 1980). In the process of enacting the Family Act 2005, the solution of joint exercise of parental rights was proposed to be enacted. Joint exercise of parental rights is possible only if the parents agree with this form. The solution that stipulates that the other parent has the right to decision making is not abandoned if the other parent exercises parental rights independently, particularly because of the fear that the rights of the other parent would actually be decreased in practice, if she/he lost the right to decision-making. This is due to the assumption that independent exercise of parental rights would be predominant in practice, as joint exercise requires agreement between parents, which is not easy to reach. It could be said that Serbian Family law is theoretically inconsistent, as the rights of parents are similar in both situations, the situation of joint and independent exercise of parental rights. However, parent who exercises parental rights independently is legal representative of the child and "the other parent" is not, while if they exercise parental rights jointly, both parents are legal representatives of the child.

The Serbian Family Act does not have an explicit provision for resolving the parental conflict. ${ }^{37}$ Having in mind the specific concept of decision-making on issues that significantly influence the child's life, which might result in a great number 
of parental conflicts in practice, the need for explicit regulation of possible ways to resolve the conflict is evident. The solution to deprive parents of parental rights is rather drastic and suitable only if the parent acts negligently. The solutions that would be suggested for resolving parental conflict are as follows. The competent authority should be the court, as the decision in question is the most important issue concerning the child. The court has the competence to make such decisions, as judges who act in family law have to be particularly specialized in this field of family law and children's rights. The courts should have different options to resolve the conflict. First, to try to conciliate the parents through family mediation conducted by competent authorities (guardianship authority, marriage or family counseling services, or another institution specialized in mediating family relations). In addition, the court should have an option to authorize one of the parents to act alone with regard to one or more specific decisions. Finally, the court should be authorized to make a decision by itself on the particular issue. The court should have discretion to choose the option(s) that are most appropriate for the current situation. This will depend on different circumstances, for instance, is the matter urgent, is the parental conflict exception or frequent, etc.

Influenced by the UN Convention on the Rights of the Child 1989 and other relevant international documents, the Serbian Family Act 2005 introduced a new concept to the rights of the child, which are regulated in a separate chapter and have been broadened compared to previous acts. In family law, the rights of the child can be divided into rights regarding status, rights derived from parent-child relations, legal competence and the right to express an opinion, the right to maintenance, and property rights. The Family Act of 2005 introduced a special procedure for the protection of the child's rights.

The Constitution also regulated the rights of the child. According to the Constitution, a child shall enjoy human rights suitable for their age and mental maturity. Every child shall have the right to personal name, entry in the registry of births, the right to learn about its ancestry, and the right to preserve his own identity (Art. 64).

Rights regarding child's status are: right to a personal name, right to a domicile, right to a citizenship and right to know who his/her parents are. ${ }^{38}$ The Family Act 2005 states that the right to a personal name is acquired at birth (Art. 13/2). The personal name consists of the name and surname (Art. 342/2). The parents determined the personal name of the child. Parents have the right to freely determine a child's name. They cannot, however, give the child a defamatory name, a name that insults the morality or a name that is contrary to the customs and opinions of the community. Except in the official language, parents also have the right to have the child's name entered into the Birth Register in the mother tongue and in the alphabet of one or both parents. If the parents are not living, unknown, if they did not determine the name in the time limit established by law, they could not agree on the child's name or gave a defamatory name, a name that insults the morality or a 
name that is contrary to the customs and views of the community, the child's name is chosen by the guardianship authority (Art. 344). The child's surname is chosen according to the surname of either one or both parents. Parents cannot give their common children different surnames. If the parents are not living, are unknown, or could not agree on the surname of the child, the child's surname is to be chosen by the guardianship authority (Art. 345).

Rights derived from parent-child relations are as follows: the right of a child to live with his/her parents, the right to be taken care of by his/her parents, in preference to all others, the right to maintain personal relationships with the parent with whom the child does not live, the right to development, upbringing, and education (Art. 60-63 FA).

A child has the right to be provided with the best living and health conditions for his/her proper and full development (Art. $62 \mathrm{FA}$ ). The protection of life and health of the child in contemporary conditions has, to a great extent, become a function of healthcare institutions. However, the role of parents is no less important. In addition to direct care about the life and health of the child, it also covers the provision of consent to any medical procedures being carried out on the child.

The Serbian Family Act 2005 provides that parents must not subject the child to degrading acts and punishments that insult the human dignity of the child, as well as being obliged to protect the child from similar actions by other persons (Art. 69/2). Historically, parents were empowered by law to punish their children. ${ }^{39}$

The Family Act 2005 introduced the obligation of parents not to leave a child of preschool age without supervision and thereby strengthen the obligation of parental care for the child (Art. 69/3).

A child has the right to education in accordance with his/her abilities, wishes, and inclinations (Art 63). The child's education, in contrast to its upbringing, which is many respects falls within the scope of the family, is carried out in schools as institutions. The Serbian Constitution provides an obligation to elementary schooling (Art. 71).

The majority was obtained by reaching 18 years of age. Full legal capacity is obtained by reaching the age of the majority or by concluding a marriage with court permission before reaching the age of the majority. The court may also permit a minor to obtain full legal capacity if he/she has reached sixteen years of age, has become a parent, and has reached the physical and mental maturity to provide independently for his/her own personality, rights, and interests (Art. 11 FA).

39 Pursuant to the Serbian Civil Code 1844, the parents had the right to return run-away of lost children and to "...what more, punish corrupted and insubordinate children with a moderate domestic punishment of castigating power ". Besides the application of 'domestic punishment', Serbian law also provided for the possibility of imprisoning children for up to ten days, pursuant to criminal law legislation, Para. 120 Serbian Civil Code, for a prison sentence - Para. 350 Penal Code, in Marković, 1920 , p. 192. The child's obligation to obedience towards the parent and tutor was provided for in Hungarian law which was applied in Vojvodina, while minors could be forced to be obedient with 'domestic discipline'. "Domestic discipline was to be carried out so as not to affect the child's health" Para. 10 Law on Tutelage and Guardianship. See: Bogdanfi, Nikolić, 1925, pp. 130-165. 
In spite of the fact that full legal capacity is obtained by reaching the age of majority, the child acquires some rights before reaching the majority. For instance, according to the Family Act, at the age of fifteen (but only if he or she is able to reason), a child has the right to change a personal name (Art. 346/1 FA), the right to inspect the Birth Register and other documentation related to his or her origin (Art. 59/3 FA), to decide which parent he or she wants to live (Art. 60/4 FA), to give consent to medical intervention (Art. 62/2 FA), to decide about maintaining personal relations with the parent he or she does not live with (Art. 61/4 FA), and to decide which secondary school he or she will attend (Art. 63/2 FA). A child who has not yet reached the age of fourteen (younger minor) can undertake legal affairs through which it exclusively obtains rights (e.g., gift contract), legal affairs by which he/she does not attain rights, obligations, or legal affairs of minor importance (e.g., purchasing of daily necessities). A child over the age of 14 (older minor) can undertake all other legal affairs with the prior or later consent of the parents. For some affairs, it is necessary to have the consent of the guardianship authority (disposal of immovable or movable property of great value). A child of the age of fifteen can undertake legal affairs through which he/she manages and disposes of income or property that he/ she has earned through employment (Art. 64/3 FA). Furthermore, at the age of ten, the child who is able to reason gives consent to adoption (Art. $98 \mathrm{FA}$ ), to fostering (Art. $116 \mathrm{FA}$ ) and has the right to propose the person who shall be appointed his/her guardian (Art. 27 FA).

In court practice, though, it might be difficult to judge if the child is "able of reason," or if the child is "capable of forming his/her own opinion," which are prerequisites for taking the child's opinion into account. There is potential risk connected with court discretion in judging a child's capabilities and the risk of continuation in a paternalistic approach that might be hidden in court assessment of such capabilities.

For the first time, the Family Act 2005 explicitly governs the child's right to express an opinion (Art. 65). The child has the right to freely express his or her opinion if the child is capable of forming an opinion. A prerequisite for the formation of an opinion is being informed, whereby the Family Act provides that the child has the right to be duly informed. The child's opinion must be given due consideration in all matters and procedures regarding his or her rights, in accordance with the age and maturity of the child. At the age of ten, the child can freely and directly express his or her opinion in any judicial or administrative proceedings in which his or her rights are being upon. In addition, the child can independently or through other persons or institutions to address the court or administrative organ and request assistance in the exercise of his or her right to freely express an opinion. The Family Act obligates state organs, administrative organs, and courts to establish the child's opinion. A child's opinion is established under a special procedure deemed suitable for the child and with the assistance of a school psychologist, guardianship authority, family counseling center, or some other institution specialized in mediating family relations, and in the presence of persons the child chooses him or herself. 


\section{Concluding remarks}

The law in some way affects the family from the very beginning by determining who is considered a family member, what are their mutual rights and obligations, how certain relationships are formed, and how they end. However, the modern understanding of the family necessarily implies respect for the self-determination principle (autonomy). The self-determination principle has consequences in the spouse/ partner relationship (e.g., marriage contract) and in the parent-child relationship (e.g., joint exercise of parental rights after divorce/separation, rights of a child).

On the other hand, there are very weak formal legal obligations of the state in taking an active role in strengthening the family, and in practice, there is virtually no involvement of the state in strengthening ties within the family before certain problems arise. The protection of the family must not be reduced only to the question of how to do it, but also to the moment or whether the protection and development of healthy family relationships must be addressed much earlier, even before the family is formed. In that sense, counseling or conversations with competent persons can be of special importance. In addition, although they are relatively foreign to Serbian culture, the popularization of prenuptial agreements and presenting future spouses/ partners with the possibilities of this agreement can contribute to the avoidance of later property disputes. Although some proposals have already found their place in the positive legislation of Serbia, the extent to which these provisions have been applied and whether they really contribute to maintaining stable family relations in situations where relations are seriously disturbed.

Statistical data on marriage and divorce in Serbia show that the marriage rate has decreased from 7,5 30 years ago to about 5 today. The divorce rate has increased, as approximately every third marriage ended in a divorce in 2018 compared to every fourth in 2011. The population growth rate decreased from $-5.2 \%$. in 2011 to $-7,7 \%$ in 2020 . Comparing mortality rate in 2019 and in 2020 it has to be noticed the mortality rate has increased in 2020 from 14,6\%o in 2019 to16,6\%o in 2020. This considerable increase is probably due to the coronavirus pandemic and illness of Covid 19.

In Serbia, the current issue is the regulation of same-sex unions. The prepared Draft Law might be classified in the group of laws that regulate registered same-sex unions similar to marriage. Considering the different concepts of the samesex union in comparative law, we would suggest that Serbia starts with some differences in the procedure for concluding and dissolution of same-sex union and marriage. For instance, to abandon the condition for witnesses to be present, abandon solemn form, and the possibility of registering a partnership outside the registrar office. For the dissolution of the same-sex union, the proposal would be to stipulate registrar as an organ with jurisdiction, instead of the court, to regulate two ways of dissolution, by mutual agreement and by unilateral demand, but without stipulation of the grounds as for the divorce. 


\section{Bibliography}

BogdAnfi, G., Nikolić N. (1925) Opšte privatno pravo koje važi u Vojvodini. Pančevo.

BRADLEY, D. (2001) 'Regulation of unmarried cohabitation in west-European jurisdictions determinants of legal policy', International Journal of Law, Policy and the Family, 15(1), pp. 22-50; https://doi.org/10.1093/lawfam/15.1.22.

BRown, A. (2019) What is the Family of Law? Oxford: Hart Publishing.

Douglas, G. (2018) Obligation \& Commitment in Family Law. Oxford: Hart Publishing.

DRAGHICI, C. (2017) The Legitimacy of Family Rights in Strasbourgh Case Law. London: Bloomsbury Publishing.

DRAŠKIĆ, M. (2017) 'Porodični zakon u očima Ustavnog suda (The Serbian Family Act in eyes of the Constitutional Court)', Perspektive implementacije evropskih standarda u pravni sistem Srbije (Perspectives of implementation of European standards in the Serbian legal system).

DWYER, J.G. (2020) The Oxford Handbook of Children and the Law. Oxford: Oxford University Press.

Huntington, C. (2014) Failure to Flourish: How Law Undermines Family Relationships Oxford: Oxford University Press.

JANIS, KAY, BRADLEY (2000) European Human Rights Law. Oxford: Oxford University Press.

KATARINA BoEle-WoelKi ET AL. (2004) Principles of European Family Law Regarding Divorce and Maintenance Between Former Spouses. Cambridge: Intersentia.

KATARINA BoEle-WoelKi ET AL. (2007) Principles of European Family Law Regarding Parental Responsibilities. Cambridge: Intersentia.

KOVAČEK STANIĆ G, SAMARDžIć S. (2020) 'Marriage in Serbian law and in Comparative Perspective', Zbornik radova Pravnog fakulteta u Novom Sadu, 54(2), pp. 545-560; https://doi. org/10.5937/zrpfns54-24802.

KOVAČEK STANIĆ G. (2002) 'Praksa Evropskog suda za ljudska prava o poštovanju porodičnog života', Evropsko zakonadvstvo, 2002/2.

KOVAČEK STANIĆ G. (2008) 'Same-sex Union: A Comparison of the Various European Legal Concepts, Colloquium on Marriage', Marriage and Quasi-marital Relationships in Central and Eastern Europe, Provo: BYA Academy Publishing SAD.

KOVAČEK STANIĆ G. (2010) 'Family autonomy in contemporary parent-child relationships'. The International Journal of Jurisprudence of the Family, Vol. 1, pp. 147-162.

KOvAČEK STANIĆ G. (1997) 'Pravo deteta da zna svoje poreklo (The Right of a Child to know about his/her origin), Novi Sad.

KOVAČEK STANić G. (2009) 'Child in a Single (Absent) Parent Family: Maintenance and Family Home', Verschraegen, B. (ed.) Family Finances, Jan Sramek Verlag.

KOVAČEK STANIĆ G. (2011) 'Multicultural Vojvodina: Influences on the formation and dissolution of marriage, Essays in Honour of Penelope Agallopoulou, T. II, Atina: Sakkoulas Publishers.

KOVAČEK STANIĆ G. (2014) 'Important Issues Concerning a Child: Decision-making and Resolving the Conflict', Harmonizacija srpskog i mađarskog prava sa pravom Evropske unije: tematski zbornik. 2. knj. = A szerb és magyar jog harmonizációja az Európai Unió jogával: tematikus tanulmánykötet. 2. köt. = Harmonisation of Serbian und Hungarian law with the European Union law: thematic collection of papers. Vol. 2. 
KovačEK StAnić G., SAMARDžić S., KovačEvić M. (2017) Razvod braka i zajedničko roditeljsko staranje kao posledica razvoda braka u teoriji i praksi', Zbornik radova Pravnog fakulteta u Novom Sadu. Vol. 51, No. 4.

KOVAČEK STANIĆ G., SAMARDŽIĆ, S. (2019) 'Assisted Reproductive Technologies: New Family Forms and Welfare of Offspring in Comparative Family Law', Rogerson, C., Antokolskaia, M., Miles, J., Parkinson, P., Vonk, M. (eds.) Family Law and Family Realities, Hague: Eleven Publishing.

MARKović, L. (1920) Građansko pravo II- Porodično parvo. Beograd: Geca Kon.

MARTIN, C., ThÉRY, I. (2001) 'The Pacs and marriage and cohabitation in France', International Journal of Law, Policy and the Family, 15(1), pp. 135-158; https://doi.org/10.1093/ lawfam/15.1.135.

NuIĆ, V. (1984) The General Law of the Catholic Church. Zagreb: Kršćanska sadašnjost.

RubELliN-DEVICHI, J. (2000) 'How Matters Stand Now in Relation to Family Law Reform' in Baninham, A. (ed.) The International Survey of Family Law. Bristol: Family Law. 